\begin{tabular}{|cc|c|}
\hline ISSN (Online): 2367-6957 & ISSN (Print): 2367-6361 \\
Izvestiya Journal of Varna University of Economics 4 (2020) & I Z V E S T I Y A \\
Journal of Varna University of Economics \\
http://journal.ue-varna.bg
\end{tabular}

\title{
FUNDING OF MICRO SCALE ENTERPRISES: IS COOPERATIVE FINANCING HELPFUL?
}

\section{Michael Segun OGUNMUYIWA ${ }^{1}$, Oluwakemi Rachel ALADEGOROYE ${ }^{2}$, Adebiyi Julius ABOSEDE ${ }^{3}$}

${ }^{1}$ Department of Business Administraton, Olabisi Onabanjo Univerity, Ago-Iwoye, Nigeria. Email: msogunmuyiwa@oouagoiwoye.edu.ng

${ }^{2}$ Departement of Cooperative and Rural Development, Olabisi Onabanjo Univerity, Ago-Iwoye, Nigeria. E-mail: chemmyracheal@yahoo.com

${ }^{3}$ Department of Business Administraton, Olabisi Onabanjo Univerity, Ago-Iwoye, Nigeria. Email: adebiyi.abosede@oouagoiwoye.edu.ng

\section{JEL: C71, G21, G23, P13 Abstract}

\section{Key words:}

Cooperative Societies, operational performance, business survival, micro scale business.

\begin{abstract}
The study investigates the influence of cooperative financing on the performance and survival of micro scale businesses, in Ogun State, Nigeria. A survey research design was adopted to generate crosssectional data, using a structured questionnaire as the research instrument. From a population of $1,165,848$ a sample size of 384 was obtained using the Raosoft sapling size formulae. Regression analysis was used to analyze the data. The findings revealed that cooperatively sourced finance has a positive and significant effect on operational performance of micro scale enterprises but no significant effect on business survival. This implies that survival of micro scale enterprises is beyond financing. The study recommends that cooperative societies, beyond financing should assist members in the area of general management of activities such as records keeping to improve the operational performance as well as the survival rate of businesses in Ogun State, Nigeria.
\end{abstract}

(C) 2020 University of Economics - Varna

Citation: OGUNMUYIWA, M. S., ALADEGOROYE, O. R., ABOSEDE, A. J. (2020). Funding of Micro Scale Enterprises: Is Cooperative Financing Helpful? Izvestiya Journal of Varna University of Economics, 64 (4), p. 430 - 443. DOI: 10.36997/IJUEV2020.64.4.430 


\section{Introduction}

Micro scale enterprises are the most common enterprises in Nigeria, engaging in different business activities to meet the demand of the public. The dominance of this type of business is a result of its ease and simplicity of formation and low capital requirement. This form of business has provided employment opportunities and served as source of income to the operators. The sustenance of this type of enterprise requires, among other things, effective financing. The role of funds in getting a business to function properly towards achieving its aims and objectives cannot be over-emphasized. Every department of a business irrespective of the size and nature requires funds. According to Leah (2017), Nwankwo, Ogbodo and Ewuim (2016), Aribaba (2012), Nwankwo, Ewuim and Asoya (2012), funding contributes greatly to how a business can accomplish its goals. Funds can be generated via many sources, mainly formal and informal sectors as identified by past studies (such as Ademilua (2017); Nwankwo et al. (2016); Oladejo (2013)). Funds are needed for smooth routine operations and to fight challenges that the business environment may pose to the continuity of the business. Due to the nature of micro scale businesses, most of the business enterprise owners source for funds from the cooperative societies.

According to Kowo, Akonbola and Akinrinola (2018), cooperative societies represent a solid and feasible economic alternative to get funds to finance a business. The cooperative societies are more common in developing economies such as Nigeria and are becoming more popular among small and micro scale business owners (Nwankwo, Ogbodo and Ewuim 2016). Onuoha (2002) opined that cooperative societies in traditional as well as in modern societies help their members in the areas of financing and other advisory services. Similarly, Ademilua (2017) believed that pooling members' economic forces to ease access to finance is the major aim of cooperative society. In this way, Ademilua (2017) and Oladejo (2013) opined that cooperative societies have promoted micro scale business owners significantly in providing soft credit. Cooperative societies are characterized with self-help value, consensus, fairness, equality, self-responsibility and team spirit in the discharge of their financial services.

The state of the Nigerian economy has made more micro scale businesses to be established. There are many challenges posed at the operational and survival levels of running micro businesses among which are limited access to pools of funds in addition to poor demand of their products, lack of managerial competence, limited access to raw materials and so on. According to Ademilua (2017), limited access to funds is one of the major obstacles of micro scale business enterprises in Nigeria 
which affected their operational performance and thereby threatening their survival to continue to exist. Banks are the major financial institutions that grant loans to businesses and the criteria they have placed on obtaining the loan are too stringent for the micro scale business owners to meet. This has resulted into micro scale business owners joining and/or forming different forms of cooperative societies to pool their financial resources for self-help. The role of the cooperative societies in Nigeria in granting credits to their members needs a re-examination to see if the needs of the micro scale enterprises are still being met in relation to their operational performance and business survival.

The objectives of this paper are to: (i) examine the influence of funds from cooperative society on operational performance of micro scale businesses in Ogun State Nigeria, (ii) investigate the effects of funds from cooperative society on the survival of micro scale businesses in Ogun State, Nigeria. The rest of the paper is divided into three sections. Section II is a review of relevant literature, while section III centres on the methodology and empirical results. Section IV houses the conclusion and recommendations of the study.

\section{Literature Review}

\subsection{Cooperative Society Finance}

Cooperative society is a self-governing group of individuals united willingly to meet their common economic, social and cultural goals via a jointly-owned and democratically controlled enterprise. Nweze (2001) defined cooperative society as an association voluntarily owned, managed and operated by its members on a non-profit basis. A Cooperative can also be seen as an association based on values of self-help, self-responsibility, democracy, equality and solidarity (Nwankwo et al., 2016). A cooperative society is a business group that is backed by law which is controlled by the members on democratic principles (Lawal, 2006). This definition implies that cooperative society is recognized by the law. Cooperative societies are the societies that are apt for achieving economic growth because they are democratically rooted, flexible, and community-based (Ademola, Oyeleye \& Afolabi, 2013). However, it is observed that cooperative societies are now into profit making, most likely because they charge interest rates that are more than enough to cover operating expenses. Nwankwo et al. (2016), thought that cooperative societies are useful as a mechanism for protecting their members against business and financial risks.

Owenvbiugie and Igbinedion (2015) expressed the idea that finance is the life wire of any business, whether developed or developing. Though human resources are 
the tools that propel any economic endeavour, fund is very prominent after human resources. Finance is also known as capital, credit and so forth. Financing sources for business is grouped into two- formal and informal sources of finance. The Informal source of finance refers to credit received from family savings, personal savings, friends, relatives and informal money lenders. The formal form of finance is credit from commercial banks and other financial institutions which are termed as external sources. The cooperative finance belongs to the informal financial structure for business finance in theory and in practice (White, Maru \& Boit, 2015).

Kowo, Akonbola and Akinrinola (2018) sees cooperative society finance as the financial support a cooperative society gives to the members based on financial capacity of the society and the contribution made by the member. It is in form of credit facilities from the cooperative societies to the members that request for it. Franken and Cook (2013) sees finance from cooperative society as the financial support from a traditional financial institution because they are community-based. Osteberg and Nilsson (2009) regarded cooperative society finance as soft loans usually given to business owners/operators to improve the capacity and general welfare of their business.

Relatively, Ochei, Ojeka, Agwu and Achugamonu (2015) identified emerging sources of funds for cooperative financing which has been practiced in developed countries. These sources include trade credit which involves seeking of fund through credit from the supplier; hire purchase and under this arrangement a cooperative society may enter into hiring rather than outright purchase of the equipment/machinery. This will help to conserve the funds of cooperatives instead of expending huge amount of money on equipment (Ochei et al. 2015). Similarly, lease arrangement, here, as noted by Ochei et al (2015), the lessor (say a finance company) purchases the goods (e. g. equipment) and leases it out to the lessee (cooperative societies) on payment of periodic rental.

\subsubsection{Micro Scale Business Performance}

The definitions of micro scale business vary from country to country. This makes micro scale business not to have a general definition. According to Ifekwem and Ogundeinde (2016), micro scale businesses are those enterprises dominated by wholesale and retail trade, manufacturing and vehicle repair/servicing, barbing salon, hairdressing salon, provision stores, welding enterprises and so on. Most of the micro scale enterprises are informal, family-owned business with low productivity value and low technological skills. According to International Labour Organisation (ILO, 1999), micro scale businesses are business enterprises that have maximum of 10 employees 
(1-10). Ebitu, Basil and Ufot (2016) see micro scale business as the enterprise with asset base of not more than 1.5 million excluding cost of land, but including working capital and staff of not more than 10 people. This implies that for an enterprise to be regarded as micro scale business, such business should not have more than 10 employees. In Nigeria, according to National Bureau of Statistics (2016) there are 36,994,578 micro enterprises out of which 9,602,249 micro enterprises are for Southwest and 1,165,848 for Ogun State.

Performance is the indicator that shows the wellbeing of a business. This if often valued by the goals previously laid down (López-Morales \& Gómez-Casas, 2014). Performance is defined by Niculescu and Lavalette (2009) as a state of competitiveness of the economic entity, reached by a level of efficiency and productivity that assures a sustainable presence on the market. According to Chigozie, Aga and Onyia (2018), organizational performance is the aggregated final products of all the organization's work procedures and exercises. Verboncu and Zalman (2015) opined that organisational performance is a particular result in the management, economics and marketing domain which gives characteristics of competitiveness, efficiency and effectiveness to the organizational, structural and procedural components. This study sees organizational performance as operational performance and survival in business.

Also, Saumu (2016) posited that the back bone of every organisation is operational performance. Operational performance is an organizational performance measured as organisational set standards such as productivity, cycle time, waste reduction, and regulatory compliance (Hwang, Han, Jun, \& Park, 2014). Every business needs to continue to operate for survival. Business survival is the effort of the management of the business to stand against pressures in form of challenges and problems from any environment of the business. According to Erengwa, Nwuche, \& Anyanwu (2017), business survival depends on the business agility to live with the environmental pressure from internal and external environment. Business survival is the continuous existence of a business activity despite the occurrence of ups and downs posed by the business environment that is categorized with uncertainties and unforeseen happenings that can intimidate the existence of business (Omoankhanlen \& Ohiria, 2017).

The collective action theory introduced by Olson (1965), focuses on activities of group of individuals towards assisting the members of the group in achieving the members' goals. This was further espoused by Marshall (1988), to emphasise that collective action theory as action taken by a group (either directly or on its behalf through an organization) in pursuit of members' perceived shared interests. The 
members of the group can contribute towards achieving the shared objective and goal in many ways like in the form of money, labour or in-kind contributions - food, wood and so on (Nwankwo et al. 2016). The collective action theory has been identified to have three key assumptions which are: there must be involvement of a group of individuals; it requires a shared interest among the individuals in the group; and mutual actions in pursuit of the shared interest.

The collective action theory is relevant to this study because it embodies the activities of cooperative societies as a group of people with common interest offering assistance to their members. According to Nwanlwo et al. (2016), the collective action theory describes the activities of cooperative society. Cooperative societies are made up of a group of people who put their resources together in order to overcome challenges that their members may face. Therefore, this study is anchored on the collective action theory because it embodies pooling resources together in order to assist members in need of funds.

\subsection{Review of Empirical Studies}

The study of Nwankwo, Ogbodo and Ewuim (2016) employed survey research design and primary data sourced through questionnaire in achieving its objectives on effect of cooperative type and age on profit performance among farmers in Anambra State. The study used descriptive statistics, regression analysis and correlation analysis to conclude that type and age profiles had significant influence on gross margin. However, this study failed to include funds from cooperative societies in its objectives.

Anta and Anam (2013) investigated the economic impact of cooperative societies on small scale business development and poverty reduction in Cross River State. The study adopted expose-facto approach and used analysis of variance (ANOVA) to find that there is influence of capital formation among cooperative societies on developing small-scale businesses. Despite including funds in its objectives, the focus of the study was not on micro scale business in Ogun State.

Ademola, Oyeleye, and Afolabi (2013) evaluated the performance of cooperative societies on women entrepreneurs in Nigeria. The study used a questionnaire to collect data from women entrepreneurs in Lagos State. The chisquare results showed that cooperative societies have significant effect on entrepreneurs. Nwankwo, Ewuim and Asoya (2012) examined the role of cooperative societies in SMEs development. The study explored the challenges facing cooperative societies in Nigeria which include bad management, corruption, inadequate financing etc. The study suggested that cooperative society needs to be reformed and monitored 
by government regulatory body (bodies). Thus, the study was not empirically conducted and emphasis was not laid on the role of funds to the SMEs development.

Aribaba (2012) examined the effects of funds provided by cooperative thrift and credit societies on the performance of small-scale businesses in Nigeria. The study used survey research design and primary data were sourced via questionnaire. The study utilized analysis of variance (ANOVA) to conclude that membership of CTCS by entrepreneurs had a positive impact on the performance of small-scale businesses in Nigeria. The study however was not carried out in Ogun State.

The effect of growth drivers on cooperative societies among Nigerian universities was conducted by Kowo, Akinbola and Akinrinola (2018). The study used a cross-sectional research design. Both analysis of variance (ANOVA) and regression analysis were employed to analyse the data. The study revealed that the interest rate of cooperative societies is a significant predictor of patronage of the cooperative. It was also revealed that there exists a relationship between loan repayment periods, savings plan and the satisfaction of members of the cooperative. However, the study was not conducted in SMEs sector and micro scale business was not included in the study objective. The study of Ademilua (2017) on the influence of cooperative society membership on women owned SMEs in Nigeria revealed that cooperative society assist women owned SMEs via financial aid in the form of loan, training, advisory among others.

\section{Methodology and Empirical Results}

Survey research design was adopted in this study. The study focused on micro scale business operators and the area of the study is the entire Ogun State, made up of twenty (20) Local Government areas and three (3) senatorial districts. Due to the large population of 1,165,848 (National Bureau of Statistics 2016), Raosoft sample size formula was used to determine the sample size of 384 from the study population. The study got data from primary source using the questionnaire as the research instrument.

The questionnaire was structured into two parts - part A and part B. Part A comprises the demographic details of the respondents and part $\mathrm{B}$ comprised the questions related to the variables under study. The questions on funds from cooperative society were adapted from study of Leah (2017) while the questions on operational performance were adapted from the study of Saumu (2016) and business survival questions were self-developed by the researchers. Five Likert rating scale was adopted to rank the responses of the respondents. The responses were subjected to a reliability test using Cronbach Alpha. Descriptive statistics was employed to analyze the data and regression analysis was used to test the hypotheses of the study. 
M. S. Ogunmuyiwa, O. R. Aladegoroye, A. J. Abosede

Funding of Micro Scale Enterprises: Is Cooperative Financing Helpful?

\subsection{Empirical Results and Findings}

\subsection{Reliability Test}

Table 1

\section{Reliability Test Results}

\begin{tabular}{lcc}
\hline \multicolumn{1}{c}{ Variables } & No of Items & $\begin{array}{c}\text { Reliability Results } \\
\text { (Cronbach Alpha) }\end{array}$ \\
\hline $\begin{array}{l}\text { Cooperative Finance } \\
\text { and Operational Performance }\end{array}$ & 11 & .787 \\
$\begin{array}{l}\text { Cooperative Finance } \\
\text { and Business Survival }\end{array}$ & 10 & .744 \\
\hline
\end{tabular}

Source: Authors' Computation, 2019.

Table 1 displayed the results of the reliability test using Cronbach Alpha. The reliability test was conducted based on the hypotheses formulated to achieve the objectives of the study. The results of the test indicated that cooperative finance and operational performance have 0.787 with 11 items, while cooperative finance and business survival have a value of 744 with 10 items. This implies that the responses of the respondents are reliable to achieve the study objectives because the Cronbach Alpha values of the hypotheses are greater than 0.70. According to Nunally (1978), Field (2009), reliability result that is over 0.70 is considered to be good for a study.

\subsection{The Model}

The model for this study relies on the Collective Action Theory which embodies pooling resources together in order to assist members in dire need of funds.

The model for the study is stated in behavioural form as follows:

$$
\begin{array}{ll}
O P M S B & =\beta_{0}+\beta_{1} C P+\mu
\end{array}
$$

Where $\mathrm{OPMSB}=$ Operational Performance of Micro Scale Businesses; $\mathrm{BSMSB}=$ Business Survival of Micro Scale Businesses and $\mathrm{CP}=$ Cooperative Finance. $\beta_{0}, \beta_{1}$, $\alpha_{0}, \alpha_{1}$ are the parameters to be estimated and $\mu=$ the stochastic term.

In a-priori terms, we expect $\beta_{0}, \beta_{1}, \alpha_{0}, \alpha_{1}$ to be positive and this is expressed thus.

$$
\beta_{0}>0, \beta_{1}>0, \alpha_{0}>, \alpha_{1}>0
$$




\subsection{Test of Hypotheses}

There are two hypotheses formulated for this study in line with the objectives and are tested with appropriate statistical tools.

H0$_{1}$ : Cooperative finance does not have a significant effect on operational performance of micro scale businesses in Ogun State.

Table 2

\section{Cooperative Finance and Operational Performance}

Dependent Variable: Operational Performance

\begin{tabular}{|c|c|c|c|c|c|c|}
\hline \multirow{2}{*}{\multicolumn{2}{|c|}{ Hypothesis One }} & \multicolumn{2}{|c|}{$\begin{array}{l}\text { Unstandardized } \\
\text { Coefficients }\end{array}$} & \multirow{2}{*}{$\begin{array}{c}\text { Standardized } \\
\text { Coefficients }\end{array}$} & \multirow[t]{2}{*}{ t-value } & \multirow[t]{2}{*}{ Sig. } \\
\hline & & B & Std. Error & & & \\
\hline \multirow[t]{2}{*}{1} & (Constant) & 2.814 & .280 & & 10.054 & .000 \\
\hline & $\begin{array}{l}\text { Cooperative } \\
\text { Finance }\end{array}$ & .312 & .076 & .368 & 4.091 & $.000 *, * *$ \\
\hline \multicolumn{7}{|c|}{$\mathrm{R}=.368, \mathrm{R}^{2}=0.135, \mathrm{~F}=16.740, \mathrm{p}=0.000$} \\
\hline
\end{tabular}

Source: Authors' Computation, 2019. SPSS, Version 22.

$*, * *$ and *** indicate significance at 1,5 and 10 percent respectively

Table 2 depicts the regression results of hypothesis one that cooperative finance does not have significant effect on operational performance of micro scale businesses in Ogun State. From the results in table 2, it is revealed that cooperative finance exhibits the appropriate sign in line with theoretical expectation and funds from cooperative society explains the variations in operational performance of micro scale business by 0.135 which is $13.5 \%$, while the remaining percentage are explained by variables not considered in this study. Also, the t-statistic showed that cooperative finance is significant in explaining changes in operational performance of micro scale businesses in Ogun State, Nigeria at both 1 and 5 percent respectively. The results further indicated that cooperative finance has a positive and significant effect on operational performance of micro scale business with a significance of the f-statistics which confirms the significance of the overall regression equation.

$\mathbf{H O}_{2}$ : Cooperative finance does not have significant effect on survival of micro scale businesses in Ogun State. 


\section{Cooperative Finance and Micro Scale Business Survival}

Dependent Variable: Business Survival

\begin{tabular}{|c|c|c|c|c|c|c|}
\hline \multirow{2}{*}{\multicolumn{2}{|c|}{ Hypothesis Two }} & \multicolumn{2}{|c|}{$\begin{array}{l}\text { Unstandardized } \\
\text { Coefficients }\end{array}$} & \multirow{2}{*}{$\begin{array}{c}\begin{array}{c}\text { Standardized } \\
\text { Coefficients }\end{array} \\
\text { Beta }\end{array}$} & \multirow[t]{2}{*}{$\mathbf{t}$} & \multirow[t]{2}{*}{ Sig. } \\
\hline & & B & Std. Error & & & \\
\hline \multirow[t]{2}{*}{1} & (Constant) & 2.338 & .535 & & 4.373 & .000 \\
\hline & $\begin{array}{l}\text { Cooperative } \\
\text { Finance }\end{array}$ & .155 & .146 & .102 & 1.063 & .290 \\
\hline
\end{tabular}

Source: Researchers' Computation, 2019. SPSS, Version 22.

*** and *** indicate significance at 1,5 and 10 percent respectively

Table 3 displays the regression results on cooperative finance and micro scale business survival. The findings showed that cooperative finance caused the changes in micro scale business survival by .010 which is about $1 \%$, while the remaining $99 \%$ are caused by other factors. Also, the relationship is not significant at any of the conventional levels. Thus, this study affirms that cooperative finance does not have any significant effect on micro scale business survival in Ogun State, Nigeria.

\subsection{Discussion of Findings}

There is no how a business irrespective of the scale or size of operation could be operated and managed without funds. Sourcing for funds seems to be cumbersome and this is one of the gaps the cooperative society is filling in developing economies like Nigeria.

The study established that financial assistance from the cooperative society has positively influenced the routine activities of micro scale businesses and their operational performance in Ogun State, Nigeria. It is evidenced that the more funds are disbursed to micro scale businesses from cooperative society, the more the efficiency in the operational performance of the micro scale businesses. However, the funds from the cooperative societies according to our findings do not determine the survival of micro scale businesses in Ogun State as there could be several other parameters determining business survival not captured in our model. Empirical evidences show that funds from the cooperative societies may not be fully and properly channelled to the purpose it is meant for. The findings of this study are similar to conclusions of previous studies such as Ademilua (2017) Antai and Anam (2013); Oladejo (2013; Nwankwo et al (2012); Aribaba (2012). 


\section{Conclusion and Recommendations}

Based on the findings, this study concludes that cooperative finance has a significant effect on operational performance of business enterprises in the sampled area, albeit, an insignificant effect was found on micro scale business survival. Thus, the study recommends that cooperative societies should continue to make funds available to their members and the members need to utilize the funds for the right purposes to enhance the operations of their business activities. In addition, cooperative societies, beyond financing should assist members in the area of general management of activities such as records keeping to improve the operational performance as well as the survival rate of businesses in Ogun State, Nigeria.

\section{References}

1. Abosede, A. J. (2012). Pecking order theory of capital structure: Another way to look at it. Journal of Business Management and Applied Economics, 5, 1-11

2. Ademilua, V. (2017). Influence of cooperative society membership on women owned SMEs in West Africa. Global Scientific Journal, 5(12), 14-29

3. Ademola, A. O., Oyeleye, O. A. \& Afolabi, O. D. (2013). Performance evaluation of cooperative societies on women entrepreneurs in Nigeria. Elixir Financial Management, 65, 19900-19904

4. Antai, A. S. \& Anam, B. E. (2013). Economic impact of cooperative societies on small scale Business development and poverty reduction in cross River State. International journal of Advanced Research in statistics Management \& finance, 1(1), 113-122

5. Aribaba, F. O. (2012). An examination of the effect of funds provided by cooperative thrift and credit societies on the performance of small-scale businesses in Nigeria. Research Journal of Finance and Accounting, 3(7), 1-6

6. Atandi, F. G. \& Wabwoba, T. B. (2013). Effect of credit on micro and small enterprises performance in Kitale Town. International Journal of Academic Research in Business and Social Sciences, 3(9), 570-583

7. Asikhia, O. \& Binuyo, O. (2012). Competitive intensity as a moderator in customer orientation - performance relationship In Nigeria. International Journal of Economics and Management Sciences, 2(3), 18-24

8. Barney, J. B. (1991). Firm resources and sustained competitive advantage. Journal of Management, 17(1), 99-120.

9. Chigozie, M. P., AGA, C. C., \& Onyia, E. (2018). Effect of human capital development in organizational performance in manufacturing industries in South-East 
Nigeria. International Journal of Academic Research in Economics and Management Sciences, 7(3), 60-78.

10. Ebitu, E. T., Basil, G. \&Ufot J. A. (2016). An appraisal of Nigeria's micro, small and medium enterprises (MSMEs): Growth, challenges and prospects. International Journal of Small Business and Entrepreneurship Research, 4(4), 1-15

11. Ebonyi, V. \& Jimoh, O. B. (2002). Cooperative movements: A way out of poverty. Lagos: Longman Publishers

12. Erengwa, K. N., Nwuche, C. A. \&Anyanwu, S. C. (2017). Employee participation and organizational survival in selected manufacturing firms in Port Harcourt, Nigeria. International Journal of Advanced Academic Research, 3(3)1 -9

13. Franken, J. R. \& Cook, M. L. (2013). Impact of board structure and process on cooperative performance. Annual General Meeting of Agricultural and Applied Economics Association, Washington, DC (No. 149420).

14. Hwang, G., Han, S., Jun, S. \& Park, J. (2014). Operational performance metrics in manufacturing process: Based on SCOR model and RFID technology. International Journal of Innovation, Management and Technology, 5(1), 72-86

15. Ifekwem, N. \& Ogundeinde, A. (2016). Survival strategies and sustainability of small and medium enterprises in the Oshodi-Isolo Local Government Area of Lagos State. Acta Universita Sapientiae, Economics and Business, 4, $103-$ 118

16. International Labour Organisation (1999). Micro and small enterprise development and poverty alleviation in Thailand. Final Report and Recommendations, June

17. Kowo, S. A., Akinbola, O. A. \& Akinrinola, O. (2018). Effect of growth drivers on cooperative societies. World Scientific News 106, 117-130

18. Lawal, T. O 2006: Introduction to modern cooperative management. Akure, alibi-Eyo\&co Ltd.

19. Leah, A. A. (2017). Factors affecting the effectiveness of bank credit in enhancing the performance of small and medium enterprises in Kenya: A case of Kisumu city. M. Sc Thesis, Jomo Kenyatta University of Agriculture and Technology.

20. Li-Ju, C. \& Shun-Yu, C. (2013). How the pecking-order theory explain capital structure. Small Business Economics, 35, 53-69.

21. López-Morales, J. S. \& Gómez-Casas, M. M. (2014). Degree of internationalization (DOI) and performance relationship: an empirical and conceptual approach. International Journal of Academic Research in Business and Social Sciences, 4(9), 39-56 
22. Marshall, G. (1988). A dictionary of sociology. New York: Oxford University Press.

23. Myers, S. \&Majluf, N. (1984). Corporate financing and investment decisions when firms have information that investors do have. Journal of Financial Economics, 13, 187-221.

24. Niculescu, M. \& Lavalette, G. (2009). Strategic growth. București: Economică Publishing House

25. Nunnally, J. (1978). Psychometric theory (2nd Ed). New York, McGrawHill

26. Nwankwo, F. Ewuim, N. \& Asoya, N. (2012). Role of cooperatives in small and medium scale enterprises (SMEs) development in Nigeria: Challenges and the way forward. International Multidisciplinary Journal, 6(4), 140-156.

27. Nwankwo, F., Ogbodo, O. C. \& Ewuim, N. (2016). Effect of cooperative type and age on profit performance: A study of cooperative societies in Awka North LGA in Anambra State, Nigeria. An International Multi-disciplinary Journal Ethiopia, 10(5), 187-203

28. Nweze, N. J. (2001). Poverty, microfinance and cooperative promotion in Nigeria. Nigerian Journal of Cooperative Studies, 1, 2-5.

29. Ailemen, I. O., Ojeka, S. Agwu, E. M. \& Achugamonu, B. U (2015). A review of the causes and effects of disparities in global financial performances of cooperative societies. Journal of Accounting and Management, 5(3), 15-26

30. Oladejo, M. O. (2013). Stakeholders perception of cooperative societies as a micro-credit delivery channel in the Nigerian financial sector reform era. International Review of Management and Business Research, 1, 460-472

31. Omoankhanlen, J. A. \& Ohiria, I. S. (2017). Workforce diversity and organisational survival of private hospitals in Nigeria. Journal of Business and Management, 19(7) 34-41.

32. Owenvbiugie, R. O \& Igbinedion, V. I (2015). Role of finance on the growth of small and medium scale enterprises in Edo State of Nigeria. Journal of Educational and Social Research, 5(1) 241-252

33. Österberg, P. \& Nilsson, J. (2009). Members' perception of their participation in the governance of Co-operatives: the key to trust and commitment in agricultural Co- operatives. Agribusiness, 25(2), 181-197.

34. Saumu, M. K. (2016). Performance measurement practices and operational performance of manufacturing firms in Kenya. MBA Thesis, University of Nairobi. 
35. Verboncu,I. \&Zalman, M. (2005). Management performance. Bucurezti, University Publishing Company.

36. Wanambisi, A. N. \& Bwisa, H. M. (2013). Effects of microfinance lending on business performance: A survey of micro and small enterprises in Kitale Municipality, Kenya. International Journal of Academic Research in Business and Social Sciences, 3(7),56-68.

37. Wernerfelt, B. (1984). A resource-based view of the firm. Strategic Management Journal,5, 171-180.

38. White, M., Maru, L. \& Boit, R. J. (2015). Financial resource as drivers of performance in small and micro enterprises in service retail sector: A case of Eldoret Municipality, Uasin Gishu Country, Kenya. Journal of Human Social Science. 15(4), $5-17$. 